\title{
POTENSI KOMBINASI INDUCED PLURIPOTENT STEM CELL-DERIVED NEURAL PROGENITOR CELL (IPSC-NPC) DENGAN HIDROGEL CHONDROITIN SULFATE SCAFFOLDS YANG MEMEDIASI BASIC FIBROBLAST GROWTH FACTOR (BFGF) SEBAGAI INOVASI TERAPI TERBARU STROKE ISKEMIK
}

\author{
Sisca $^{1}$, Nurul Azizah ${ }^{2}$, M. Salas Al Aldi ${ }^{3}$ \\ 1,2,3 Program Studi Pendidikan Dokter, Fakultas Kedokteran, Universitas Hasanuddin, Makassar
}

\begin{abstract}
Ischemic stroke is the most common type of stroke and is the disease with the highest mortality and disability rates in the world. Current therapies for treating stroke remain challenging for researchers because treatments have not been found that can regenerate brain tissue lost due to infarction. The use of Neural Progenitor Cell (NPC) derived Pluripotent Stem Cell (iPSC) is a study that is at the forefront of the preclinical testing phase because it is known to become and replace neurons and promote endogenous recovery mechanisms such as angiogenesis. However, there are barriers to the use of NPC especially in the pathophysiology of stroke which causes resistance to cellular therapy. Therefore, it is necessary to combine NPC with Scaffold using hydrogel-based Chondroitin sulfate-A (CS-A) which can increase blood flow to the core of the stroke and increase neurotropic affinity. This combination produces excellent therapeutic synergy with the main effect mediated by the basic fibroblast growth factor $(b F G F)$ which repairs tissue damage in the infarct area. To determine the potential for the combination of NPC with CS-A hydrogel in the treatment of ischemic stroke. This Literature Review was prepared using the literature study method by collecting valid journals based on specific inclusion and exclusion criteria. The combination of NPC with Hydrogel CS-A significantly improved vascular repair, cortical blood flow and sensorimotor behavior outcomes after stroke. The increase that occurs is mediated through stimulation of bFGF release which promotes tissue repair. The effectiveness of NPC administration can be significantly improved with the CS-A hydrogel combination and has been proven in various tests so that it is hoped that it will become the latest effort in ischemic stroke therapy.
\end{abstract}

Keywords: ischemic stroke, neural progenitor cell, chondroitin sulfate, basic Fibroblast Growth Factor

Abstrak

Stroke iskemik adalah jenis stroke yang paling umum terjadi dan merupakan penyakit dengan angka kematian dan kecacatan tertinggi di dunia. Terapi yang ada saat ini dalam menangani stroke masih menyisakan tantangan bagi para peneliti karena belum ditemukannya perawatan yang dapat meregenerasi jaringan otak yang hilang akibat infark. Penggunaan Neural Progenitor Cell (NPC) turunan induced Pluripotent Stem Cell (iPSC) merupakan studi yang berada paling depan dalam tahapan uji praklinis karena diketahui dapat menjadi dan menggantikan neuron serta mempromosikan mekanisme pemulihan endogen seperti angiogenesis. Namun, terdapat hambatan dari penggunaan NPC utamanya pada patofisiologi stroke yang menyebabkan adanya resistensi terhadap terapi seluler. Oleh karena itu, diperlukan kombinasi NPC dengan Scaffold menggunakan Chondroitin sulfate-A (CS-A) berbasis hidrogel yang dapat meningkatkan aliran darah ke inti stroke serta meningkatkan afinitas neurotropik. Kombinasi ini menghasilkan sinergitas terapi yang sangat baik dengan efek utamanya dimediasi oleh basic Fibroblast Growth Factor (bFGF) yang akan memperbaiki kerusakan jaringan di daerah infark. Untuk mengetahui potensi kombinasi NPC dengan Hidrogel CS-A dalam pengobatan stroke iskemik. Literature Review ini disusun menggunakan metode studi pustaka dengan mengumpulkan jurnal yang valid berdasarkan kriteria inklusi dan eksklusi khusus. Kombinasi NPC dengan Hidrogel CS-A secara signifikan meningkatkan perbaikan vaskular, aliran darah kortikal dan hasil perilaku sensorimotor setelah stroke. Peningkatan yang terjadi dimediasi melalui stimulasi pengeluaran bFGF yang mendorong perbaikan jaringan. Efektivitas pemberian NPC secara signifikan dapat ditingkatkan dengan kombinasi Hidrogel CS-A dan telah terbukti dalam berbagai pengujian sehingga diharapkan dapat menjadi upaya terbaru dalam terapi stroke iskemik.

Kata Kunci: ischemic stroke, neural progenitor cell, chondroitin sulfate, basic Fibroblast Growth Factor 


\section{PENDAHULUAN}

Stroke merupakan penyakit dengan angka kematian tertinggi kedua di dunia dan memberikan penurunan kualitas hidup yang sangat drastis bagi penderitanya. Secara global, stroke mempengaruhi 13,7 juta orang dengan 5,5 juta kematian per tahunnya. Di Indonesia, masalah stroke menjadi semakin penting untuk diperhatikan karena angka kejadian stroke di Indonesia merupakan yang terbanyak di kawasan Asia. Prevalensi penderita stroke di Indonesia pada tahun 2018 sebesar $10,9 \%$ atau sekitar 713.783 orang. Penyakit stroke dibagi menjadi dua macam yaitu stroke iskemik dan stroke hemoragik. Stroke iskemik adalah jenis stroke yang paling umum terjadi dengan angka kejadian berkisar $80-85 \%$ dan risiko kematian sekitar 20\%. Angka kelangsungan hidup pasien stroke iskemik setelah onset pertama sekitar $65 \%$ pada tahun pertama, 50\% pada tahun kelima, 30\% pada tahun ke delapan, dan $25 \%$ pada tahun ke sepuluh.

Stroke iskemik terjadi ketika pembuluh darah di leher atau otak tersumbat. Penyumbatan dapat disebabkan oleh pembentukan gumpalan di dalam pembuluh darah otak atau leher (trombosis), gumpalan dari bagian lain tubuh seperti jantung ke otak (emboli), atau penyempitan arteri yang mengarah ke otak (stenosis). Penyumbatan pembuluh darah di otak menyebabkan kegagalan energi, asidosis, pelepasan glutamat yang berlebih, peningkatan kadar $\mathrm{Ca}^{+2}$ intraseluler, pembentukan radikal bebas dan peradangan yang pada akhirnya menyebabkan kematian sel. Faktor risiko terjadinya stroke iskemik meningkat dengan bertambahnya usia. Namun kebiasaan merokok, hipertensi, hiperkolesterolemia, diabetes dan kegemukan juga berperan dalam terjadinya stroke iskemik.

Diperlukan tindakan segera untuk pengobatan dan pencegahan kecacatan yang disebabkan oleh stroke iskemik. Berbagai macam terapi telah digunakan, namun belum ada terapi yang efektif untuk menangani stroke iskemik. Hingga saat ini, hanya ada satu pengobatan yang disetujui oleh FDA (Food and drug administration) untuk stroke iskemik yaitu obat trombolitik berupa aktivator plasminogen jaringan (tPA). Namun, batas waktu pemberian obat ini terbatas pada maksimal 4,5 jam setelah onset stroke sehingga kurang dari 5\% pasien stroke mendapatkan manfaat dari perawatan trombolitik ini. Banyak kandidat obat neuroprotektif untuk mengobati stroke, gagal menunjukkan manfaat dalam uji klinis. Tanpa perawatan yang efektif, pasien stroke yang bertahan hidup sering memiliki gangguan neurologis dan cacat selama berbulan-bulan hingga bertahuntahun setelah stroke.

Strategi alternatif yang menargetkan fase regeneratif yang tertunda telah menarik perhatian dengan harapan dapat memperbaiki jaringan otak yang rusak dan meningkatkan pemulihan fungsional dari sel. Salah satu terapi yang menjanjikan dalam penanganan stroke iskemik adalah melalui dukungan trofik/pertumbuhan dan penggantian sel. Proliferasi sel merupakan bagian awal pada proses penggantian sel. Pada otak, proliferasi sel diperankan oleh sel induk saraf (neural stem cell, NSC) dan sel progenitor saraf (neural progenitor cell, NPC). NSC memiliki sifat — self-renewll yang akan berkembang menjadi NPC dan akan aktif berproliferasi. NPC kemudian bermigrasi dan akhirnya berdiferensiasi menjadi neuron ataupun glia. Sel-sel progenitor saraf (NPC) inilah yang dapat ditransplantasikan ke otak yang mengalami 
iskemik. Sel-sel yang ditransplantasikan ini dapat berdiferensiasi menjadi sel-sel saraf dan pembuluh darah dengan mengeluarkan faktor-faktor trofik, mengurangi kematian sel, meningkatkan neurogenesis dan angiogenesis endogen. Namun, perfusi yang terganggu dan degradasi jaringan setelah iskemia menciptakan lingkungan yang tidak ramah dan resisten terhadap terapi seluler.

Menurunkan resistensi transplantasi dan meningkatkan aliran darah ke inti stroke menjadi kunci utama untuk mengatasi rintangan dalam terapi seluler. Hidrogel adalah bahan pembawa biokompatibel yang dapat digunakan untuk meningkatkan kelangsungan hidup, diferensiasi, potensi trofik dan integrasi fungsional dari sel yang ditransplantasikan. Chonsroitin Sulfate-A (CS-A) merupakan salah satu bahan hidrogel yang dapat menciptakan lingkungan mikro yang menguntungkan untuk transplantasi dan regenerasi dari sel. NPC yang dibalut hidrogel CS-A secara sinergis meningkatkan angiogenesis, remodeling pembuluh darah, aliran darah lokal di otak dan hasil perilaku setelah stroke iskemik pada tikus. Selain itu, pensinyalan faktor pertumbuhan fibroblas dasar (bFGF) yang diperkuat oleh pengayaan dalam hidrogel CS-A juga hadir untuk memediasi manfaat yang diberikan pada jaringan stroke setelah diberikan kombinasi CS-A dan NPC. Oleh karena itu itu, strategi kombinasi NPC dengan Chondroitin sulfate-A (CS-A) dapat menjadi inovasi terbaru dalam terapi stroke iskemik.

\section{METODE}

Literature Searching dilakukan secara sistematik pada google Scholar dan NCBI. .5 kata kunci yang digunakan pada tulisan ini yaitu "Stroke iskemik", -IPSC\|, "Neural Progenitor cell", "Chondroitin sulfate" dan -basic Fibroblast Growth Factorll. Jurnal terbaru dikumpulkan dan diseleksi sesuai dengan tema yang diangkat Setelah itu, kriteria inklusi diberikan untuk menyaring hasil literature searching yang dilakukan. Kriteria inklusi yang dimasukkan yaitu sesuai dengan kata kunci dan jurnal terpublikasi dalam 10 tahun terakhir. Selanjutnya untuk kriteria eksklusi yaitu keterbatasan dalam mengakses jurnal. Setelah memenuhi kriteria tersebut, isi jurnal ditambahkan sebagai referensi dan secara keseluruhan terdapat 46 jurnal yang dimasukkan sebagai referensi dalam menyusun literature review ini.

\section{HASIL DAN PEMBAHASAN}

\section{Sel Saraf Progenitor (NPC) yang Berasal dari Sel Punca Pluripoten yang Diinduksi (IPSC)}

Terapi sel punca menjadi terapi penyakit regeneratif yang menjanjikan dan paling banyak dikembangkan saat ini, terutama pada kerusakan otak akibat stroke. Sel punca dapat menggantikan sel yang telah rusak di otak. Sel punca multipoten maupun pluripoten terbukti memiliki efek parakrin yang dapat mengurangi kematian sel dan menginduksi pertumbuhan sel baru sehingga dapat terjadi regenerasi pada sel otak yang telah rusak. Beberapa penelitian telah membuktikan adanya potensi perbaikan jaringan dan pemulihan fungsional pasca stroke melalui pemberian sel saraf progenitor (Neural Progenitor Cell, NPC) yang berasal dari sel punca pluripoten yang diinduksi (induced Pluripotent Stem Cell, iPSC), iPSC-NPC.

IPSC ini merupakan sel punca yang bersifat pluripoten atau dapat membentuk 
berbagai jenis sel tubuh (seperti sel neuron, jantung, pankreas, dan hati). IPSC dapat diprogram ulang dari sel somatik dewasa yang dibentuk menggunakan empat faktor transkripsi, yaitu Oct3/4, Sox2, c-Myc, and Klf4. IPSC memiliki karakteristik yang mirip dengan ESC (Embryonic Stem Cell) namun lebih menguntungkan pada masalah moral dan etik serta kemungkinan allogeneic immune rejection yang lebih kecil, oleh karena IPSC ini dapat diambil dari sel somatik orang yang sama, seperti fibroblas kulit. IPSC-NPC ini berpotensi memperbaiki jaringan dan fungsional otak pasca stroke dengan berbagai cara, seperti menggantikan sel yang rusak, memberikan dukungan pertumbuhan sel, anti-inflamasi, menstimulasi persinyalan endogen untuk merangsang plastisitas dan regenerasi neuron, serta interaksi regulasi dengan sel endogen seperti astrosit dan oligodendrosit.

Dalam kondisi stroke iskemik, transplantasi sel punca menjadi tidak efektif, oleh karena aliran darah ke daerah yang mengalami stroke berkurang sehingga sel yang baru akan sulit untuk tumbuh. Selain itu, transplantasi IPSC-NPC pada daerah peri-infark dikatakan cukup invasif karena area tersebut sensitif sehingga sel punca mudah rusak. Namun, beberapa penelitian telah membuktikan bahwa transplantasi di area peri-infark dengan lingkungan mikro yang mendukung akan memberikan ketahanan pada sel punca tersebut. Untuk itu, digunakan hidrogel chondroitin sulfate-A (CS-A) untuk menciptakan lingkungan mikro yang sesuai pada area inti stroke sehingga membantu dalam proses transplantasi dan regenerasi sel otak.

\section{Hidrogel CS-A}

Hidrogel adalah material struktur tiga dimensi (3D) yang terdiri dari polimer hidrofilik yang menahan sejumlah besar air. Biokompatibilitas yang baik, fleksibilitas dalam pembuatan, dan komposisi variabel yang dapat menyesuaikan dengan karakteristik fisik yang diinginkan (mirip dengan kondisi fisiologis) menjadikan hidrogel banyak digunakan dalam aplikasi biomedis Hidrogel dapat berfungsi sebagai perancah (scaffold) yang menyediakan struktur 3D untuk rekayasa jaringan, sebagai pembawa untuk enkapsulasi sel atau pengiriman obat, dan sebagai perekat atau bertindak sebagai kontrol reversibel dari sel. Memformulasikan komponen hidrogel dari matriks ekstraselular (Extracellular Matrix, ECM) dapat mengurangi imunogenisitas, menjaga sifat bio-induktif, dan memungkinkan terjadinya degradasi melalui mekanisme aslinya.

Chondroitin sulfate (CS) merupakan makromolekul bioaktif yang diturunkan secara alami dan menjadi komponen utama matriks ekstraseluler (ECM) yang terlibat dalam regenerasi dan respons terhadap cedera otak. CS didistribusikan secara luas di berbagai organisme dan telah menarik banyak perhatian di bidang pemberian obat dan rekayasa jaringan karena sifatnya yang tidak beracun, biodegradasi, dan biokompatibel yang kuat. Unsur sulfat dari rantai disakarida CS yang melekat pada proteoglikan CS otak asli memfasilitasi pengikatan, retensi, presentasi faktor pertumbuhan seperti bFGF (basic Fibroblast Growth Factor) dan faktor neurotropik untuk mempromosikan proliferasi dan diferensiasi sel induk/progenitor saraf (NSPC) yang tepat waktu untuk meningkatkan pertumbuhan neurit (Gambar 1). 


\section{Subventricular zone}

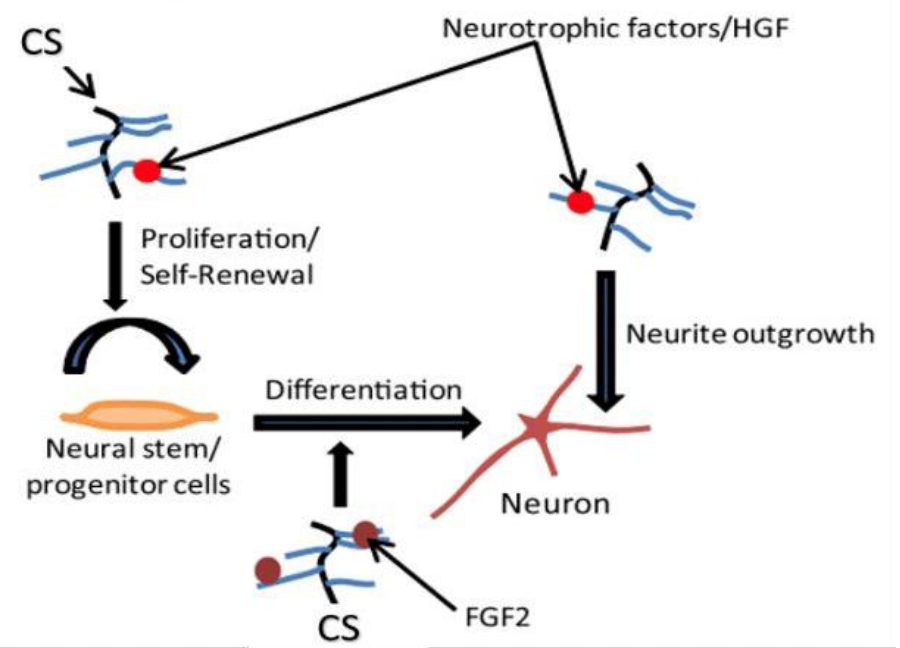

Gambar 1. Mekanisme dari CS yang merupakan komponen utama sel punca saraf di zona serebroventriular (SVZ) dalam memodulasi sel induk saraf dan keturunannya

CS biasanya dibagi menjadi CS-O, CSA, CS-C, CS-D, CS-E. Lima jenis ini dibagi sesuai dengan posisi dan derajat sulfida. Selain variabilitas dalam kelompok sulfat, berbagai jenis CS sangat heterogen dalam hal aktivitas biologis dan sifat farmakologisnya. CS-A terlibat dalam diferensiasi dan migrasi sel induk saraf endogen, pertumbuhan neurit/akson dan angiogenesis. Faktor regeneratif seperti bFGF, faktor neurotropik turunan otak (BDNF) dan protein imunomodulator yaitu interleukin 10 (IL-10) memiliki afinitas yang lebih tinggi untuk CS-A dibandingkan dengan jenis lainnya. CS-A memainkan peran penting dalam perbaikan otak setelah cedera dengan mempromosikan proliferasi, migrasi, dan kelangsungan hidup sel endotel. CS-A selalu disiapkan untuk digunakan dalam rekayasa jaringan yang digabungkan dengan pemanfaatan hidrogel. Oleh karena itu, penggunaan hidrogel CSA berfungsi sebagai sistem pembawa yang efektif dalam terapi seluler.

\section{Enkapsulasi CS-A dapat Meningkatkan Potensi Terapi Seluler untuk Stroke}

Dalam penelitian yang dilakukan oleh McCrary, M. R. dkk. (2020) menggunakan model stroke iskemik yang ditargetkan pada korteks sensorimotorik tikus. Korteks sensorimotorik ini bertanggung jawab atas sensasi dan fungsi motorik kumis dan kaki depan tikus. Dalam penelitiannya, dilakukan uji defisit unilateral, sensorimotor, dan motorik dengan hasil sebagai berikut:

1. Menguji defisit unilateral menggunakan uji sudut.

Tikus dimasukkan ke arena sudut yang dipantau, kemudian tikus akan mendeteksi perbatasan dengan menggunakan kumisnya, lalu berbalik ke belakang untuk keluar dari sudut tersebut. Setelah stroke iskemik di korteks sensorimotor kanan, intensitas tikus belok kanan lebih sering dibandingkan belok kiri karena kurangnya sensasi pada kumis kiri yang mengakibatkan peningkatan rasio belok 
kanan dibandingkan dengan belok kiri. Setelah transplantasi CS-A + NPC, rasio giliran dipulihkan secara signifikan 1 minggu setelah perawatan (Gambar 3A).

2. Fungsi sensorimotor menggunakan uji pelepasan adhesif

Fungsi sensorimotor kaki depan dievaluasi menggunakan uji pelepasan adhesif dengan tugas terperinci yang mengharuskan tikus untuk merasakan dan melepaskan stiker yang diletakkan pada cakarnya. Tikus yang diobati dengan CS-A + NPCs menunjukkan peningkatan waktu yang signifikan untuk menghilangkan stiker pada cakarnya 1 minggu setelah transplantasi (Gambar 3B).

2. Fungsi motorik menggunakan uji tarik isometrik volusi

Karena tingginya tingkat pemulihan fungsional pada uji sudut dan tes pelepasan adhesif setelah 3 minggu induksi ministroke ke korteks sensorimotor (Gambar 3A, B), maka dilakukan pengujian fungsi motorik kaki menggunakan uji tarik isometrik volusi, yang lebih mudah mendeteksi kerusakan halus pada fungsi motorik kaki depan dan menguji ketangkasan. 2 minggu setelah transplantasi, tikus yang diobati dengan CS-A + NPC menunjukkan peningkatan kekuatan tarikan dibandingkan dengan kelompok perlakuan palsu dan peningkatan hit superior dibandingkan dengan kelompok kontrol (Gambar 3C, D).

Hasil perilaku ini menunjukkan pemulihan fungsional korteks sensorimotor dan membuktikan bahwa enkapsulasi CS-A dapat meningkatkan potensi terapi terapi seluler untuk stroke.

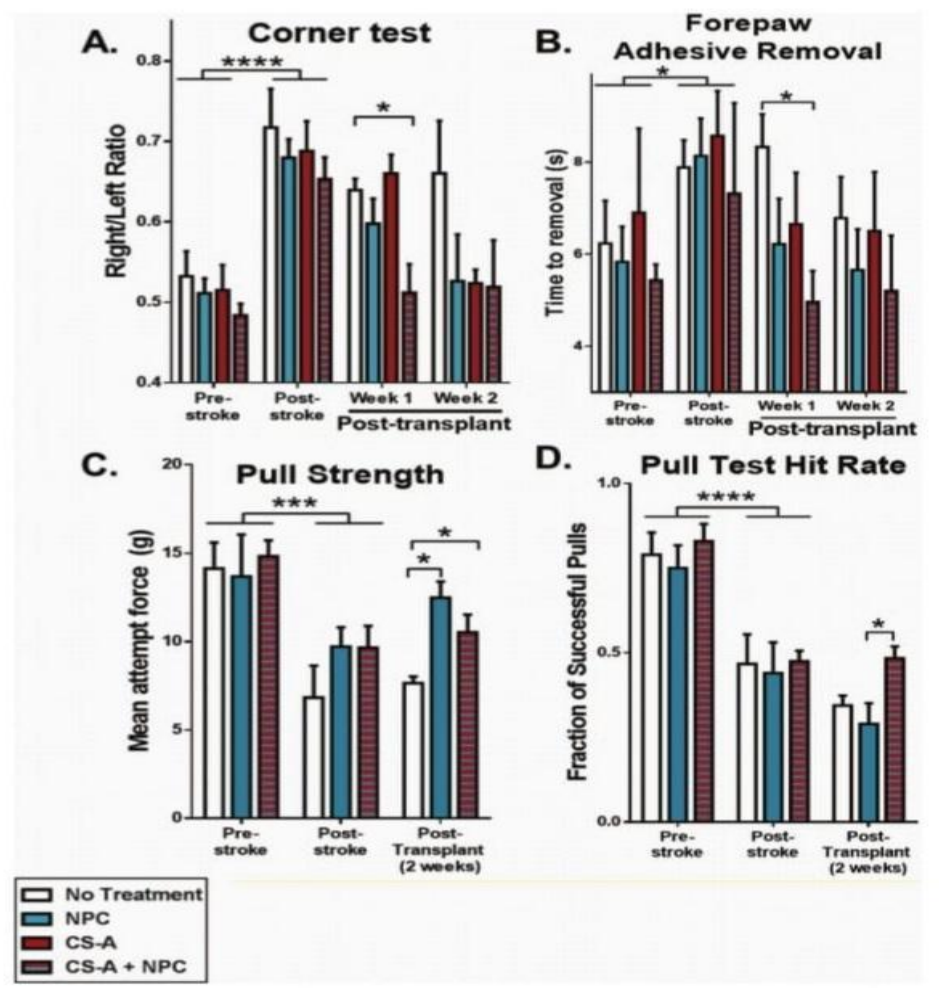

Gambar 3. A) Analisis uji sudut, B) Analisis uji pelepasan adhesif, C) Analisis kekuatan tarikan. D) Analisis hit rate dalam uji tarik. *, ***, dan **** masing-masing menunjukkan $\mathrm{p}$ $<0,05$, $\mathrm{p}<0,0005$, dan $\mathrm{p}<0,0001$ (2-way ANOVA, uji perbandingan berganda Bonferroni) 
Efektivitas Kombinasi NPC dengan CSA Berbasis Hidrogel yang Dimediasi Melalui basic Fibroblast Growth Factor (bFGF)

Sinergitas dari kombinasi terapi menggunakan NPC dan CS-A memiliki efek yang sangat baik dengan efektivitasnya dalam neovaskularisasi dan regenerasi jaringan. Dalam pengujiannya, ditemukan bahwa kombinasi terapi ini utamanya meningkatkan potensi pelepasan dari bFGF pada daerah infark. bFGF ini telah diketahui memiliki peran penting dalam perbaikan otak setelah cedera, dengan mempromosikan proliferasi, migrasi, dan mempertahankan keberlangsungan hidup sel endotel. Selanjutnya, peningkatan bFGF ini juga merangsang faktor lain seperti Vascular Endothelial Growth Factor (VEGF) yang bekerja sama dengan bFGF untuk mempromosikan angiogenesis.
Hipotesis dari bFGF yang memiliki peran sentral dalam memediasi efek NPC + CS-A dibuktikan secara in Vitro maupun in vivo. Pada hasil pengujian Western Blotting, bFGF ini diperkaya di daerah stroke setelah 1 minggu transplantasi dari $\mathrm{NPC}+\mathrm{CS}-\mathrm{A}$. Bukan hanya bFGF, peningkatan ini diikuti oleh ekspresi VEGF, p-STAT3 dan p-AKT, yang merupakan faktor primer dalam molekul pensinyalan yang terlibat dalam aktivasi endotel yang secara jelas dapat dilihat pada (Gambar 2). Konfirmasi mediasi bFGF ini dilanjutkan dengan pengujian in vivo dengan penambahan anti-bFGF pada perlakuan dan didapatkan hasil bahwa dengan adanya anti-bFGF ini, angiogenesis dan regenerasi berkurang secara signifikan selama 2 pekan pengamatan. Sehingga, hasil ini menunjukkan secara pasti bahwa bFGF memediasi kombinasi NPC + CS-A dalam remodeling vaskular, pemulihan aliran darah, dan pemulihan perilaku sensorimotor.

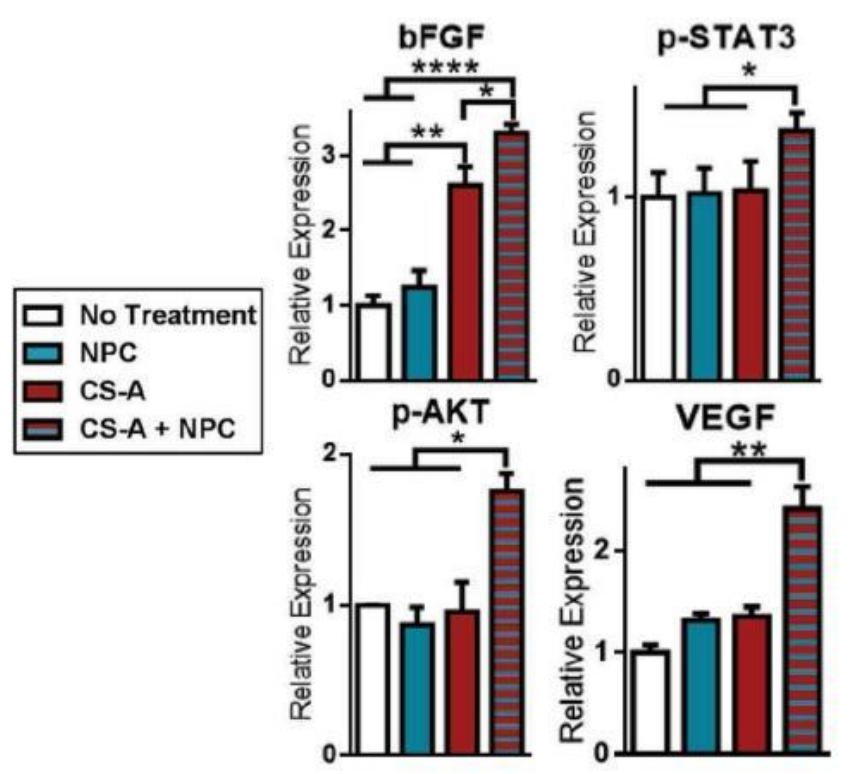

Gambar 2. Kuantifikasi intensitas hasil Western Blotting.. *, **, dan *** masing- masing menunjukkan $\mathrm{p}<0,05$, $\mathrm{p}<0,005$, dan $\mathrm{p}<0,0005$. 


\section{Kombinasi NPC dengan CS-A Dapat Meningkatkan Mikrovaskular dan Angiogenesis}

Untuk menilai efek CS-A + NPC dalam proses peningkatan jumlah mikrovaskular serta angiogenesis pada hewan coba yang mengalami stroke, dilakukan analisis vaskularisasi serta diukur kadar Glut1, yang merupakan isoform transporter glukosa yang terutama diekspresikan pada sel endotel otak serta astrosit, dan BrdU (Bromodeoxyuridine), yang merupakan analog timidin yang menggabungkan DNA pada fase $\mathrm{S}$ dalam siklus sel. BrdU secara imunohistokimia telah berperan dalam studi pengembangan sistem saraf, serta mengonfirmasi terjadinya neurogenesis pada otak mamalia dewasa, termasuk pada manusia. Pemeriksaan kadar Glut1 dan BrdU ini dilakukan pada daerah inti stroke pada 4 kelompok tikus dengan perlakuan berbeda. Kelompok pertama tidak diberikan pengobatan apapun, kelompok kedua diberikan NPC saja, kelompok ketiga diberikan CS-A saja, dan kelompok keempat diberikan kombinasi NPC dan CSA.

Dalam penelitian yang dilakukan oleh McCrary M.R. dkk (2020), menunjukkan adanya peningkatan jumlah mikrovaskular pada area inti yang mengalami stroke setelah pemberian CS-A + NPC (Gambar 3A). Selain itu pada gambar 3B, juga ditemukan kadar Glut1 + BrdU yang meningkat pada kelompok yang diberikan CS-A + NPC, yang menunjukkan bahwa pengobatan ini dapat meningkatkan angiogenesis serta kepadatan pembuluh darah pada area otak yang mengalami stroke.
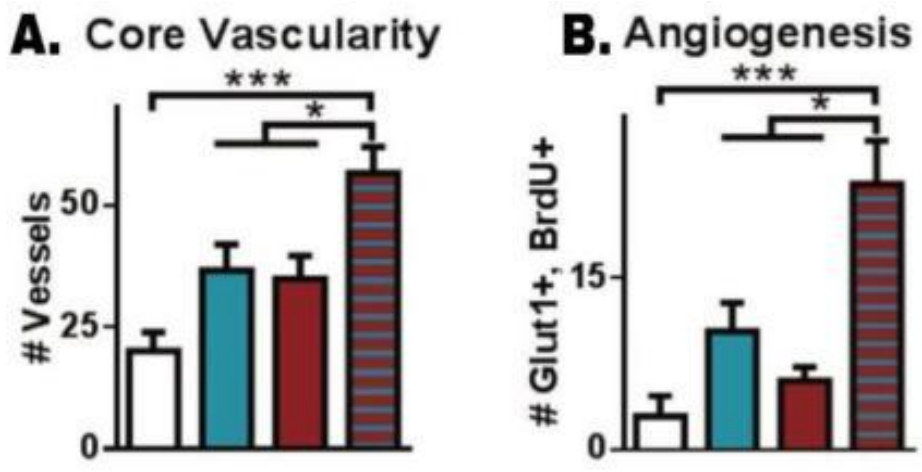

Gambar 3. A) Analisis vaskularisasi di area inti stroke pada keempat kelompok uji coba. B) Analisis angiogenesis dengan melihat kadar Glut1+BrdU. $n=8-12$ per kelompok. *, **, dan $* * *$ mengindikasikan $\mathrm{p}<0.05, \mathrm{p}<0.005$, and $\mathrm{p}<0.0005$ (1-way ANOVA, Tukey's posthoc)

\section{Kombinasi NPC dengan CS-A Meningkatkan Rekrutmen Arteri Kolateral Pial dan Memperbaiki Aliran Darah Pasca Stroke}

Pada saat terjadi iskemik otak akibat stroke, salah satu mekanisme utama sebagai pemulihan dan pertahanan jaringan otak ialah dengan membentuk arteri kolateral pial atau biasa disebut sebagai arteri kolateral leptomeningeal yaitu arteri kecil yang bergabung dengan cabang kortikal terminal arteri serebral utama (medial, anterior dan posterior) di sepanjang permukaan otak. 
Berdasarkan hal tersebut, maka dilakukan penilaian jumlah rekrutmen arteri kolateral pial untuk membuktikan peran CS- A + NPC dalam penanganan stroke iskemik. Pada gambar 4A terlihat persentase rekrutmen arteri kolateral pial pada kelompok yang diberikan CS-A + NPC lebih tinggi dibanding kelompok lainnya. Selain itu juga dinilai aliran darah menggunakan Laser Doppler Flowmetry pada keempat kelompok saat sebelum stroke (pre-stroke), setelah terjadi stroke (post- stroke), dan setelah dilakukan perlakuan/transplantasi NPC, CS-A, dan CS- A + NPC. Diperlihatkan adanya penurunan aliran darah dari pre-stroke ke post-stroke yaitu sekitar 3,8 menjadi 2,5 unit perfusi. Namun, setelah diberikan pengobatan menggunakan CS-A + NPC, dalam 1 dan 2 minggu, terjadi peningkatan aliran darah yang signifikan dibandingkan dengan kelompok yang lainnya (Gambar 4B).
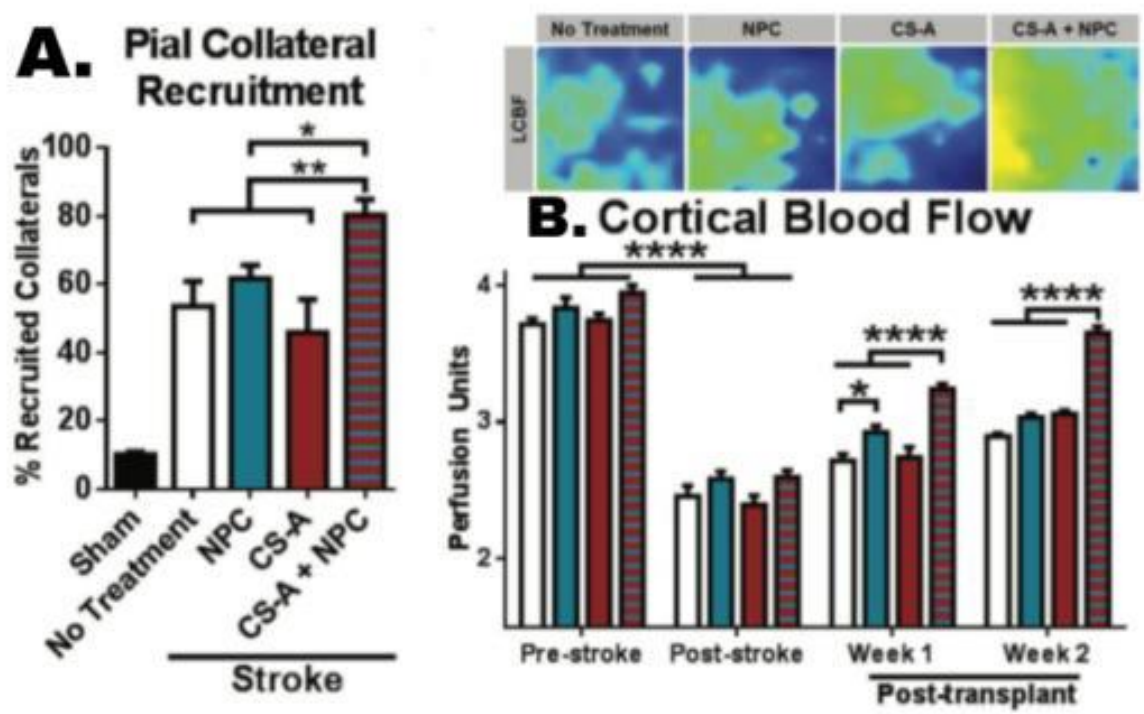

Gambar 4. A) Analisis rekrutmen arteri kolateral pial (skala $=0.2 \mathrm{~mm}) . \mathrm{n}=5-6$ per kelompok. * dan ** menunjukkan $\mathrm{p}<0.05$ dan $\mathrm{p}<0.005$ (1 way ANOVA, Holm-Sidak post-hoc versus CS-A + NPC). B) Laser Doppler Flowmetry serta analisis kuantitas untuk melihat aliran darah otak lokal pada area yang diberi perlakuan. $\mathrm{n}=8-12$ per kelompok. * dan $* * * *$ menunjukkan $\mathrm{p}<0.05$ and $\mathrm{p}<0.0001$ (2-way ANOVA, Bonferroni's correction).

\section{KESIMPULAN DAN SARAN}

\section{Kesimpulan}

Neural Progenitor Cell (NPC) yang dipadukan dalam scaffold chondroitin sulfate $-\mathrm{A} \quad(\mathrm{CS}-\mathrm{A})$ berbasis hidrogel menjadi jawaban tantangan terapi sel punca dan regenerasi jaringan saat ini. CS-A bekerja dengan menurunkan resistensi stroke dalam terapi seluler dan terbukti memberikan efek yang sangat baik dalam pengujian in vitro maupun in vivo.

Enkapsulasi NPC dengan CS-A secara signifikan meningkatkan angiogenesis dan kepadatan vaskular pada jaringan iskemik, sehingga efek ini menyebabkan pemulihan fungsional aliran darah kortikal dan sensorimotor. CS-A juga dapat memperluas potensi trofik NPC untuk perawatan stroke iskemik yang utamanya melalui mediasi basic Fibroblast Growth Factor (bFGF). 
Oleh karena itu, metode ini diharapkan dapat menjadi inovasi terbaru dalam terapi pengobatan stroke iskemik kedepannya.

\section{Saran}

Perlunya dilakukan penelitian lebih lanjut menggunakan metode ini dengan pengujian klinis pada subjek manusia untuk melihat efektivitas dan efek samping yang akan terjadi.

\section{DAFTAR PUSTAKA}

1. Yamashita, T., \& Abe, K. Recent Progress in Therapeutic Strategies for Ischemic Stroke. Cell Transplantation. 2016, 25(5), 893-898.

2. World Stroke Organization. WSO global stroke fact sheet. 2019.

3. Balitbang Kemenkes RI. Riset Kesehatan Dasar; RISKESDAS. Jakarta: Balitbang Kemenkes RI. 2018.

4. Rohmatul, L. Hubungan Karakteristik Penderita Dan Hipertensi Dengan Kejadian Stroke Iskemik. Surabaya 2017.

5. Mozaffarian D, Benjamin EJ, Go AS, Arnett DK, Blaha MJ, Cushman M, et al. Heart Disease and Stroke Statistic $2015 \quad$ Update. Circulation. 2015;131(4):29-322.

6. Wallace, J. B. Researchers document troubling rise in strokes in young adults, starting at age 25 . The Washington Post. 2016.

7. National Institute of Neurological Disorders and Stroke. Brain basics: Preventing stroke. 2016.

8. Xing, C., Arai, K., Lo, E. H., \& Hommel, M. Pathophysiologic Cascades in Ischemic Stroke.
International Journal of Stroke. 2012, 7(5), 378-385.

9. Susan A. Randolph. Ischemic Stroke. University of North Carolina at Chapel Hill. 2016.

10. Adeoye O, Hornung R, Khatri P, Kleindorfer D. Recombinant tissuetype plasminogen activator use for ischemic stroke in the United States: a doubling of treatment rates over the course of 5 years. Stroke. 2011; 42:1952-5.

11. Monica, C. Todd C. Deveau, et al. Transplantation of iPS cell-derived neural progenitors overexpressing SDF- $1 \alpha$ increases regeneration and functional recovery after ischemic stroke. Oncotarget, 2017, Vol. 8, No. 57, pp: 97537-97553.

12. McCrary, M. R., Jesson, K., Wei, Z.Z., Logun, M., Lenear, C., Tan, S., Wei, L. Cortical Transplantation of BrainMimetic Glycosaminoglycan Scaffolds and Neural Progenitor Cells Promotes Vascular Regeneration and Functional Recovery after Ischemic Stroke in Mice. Advanced Healthcare Materials. 2020.

13. Vidya, I. Proliferasi dan Plastisitas Neuronal. Researchgate. Universitas Gadjah Mada. 2015.

14. Lazarov, O., Mattson, M.P., Peterson, D.A., Pimplikar, S.W., dan van Praag, $\mathrm{H}$. When neurogenesis encounter aging and disease. Trends in Neurosciences. 2010, 13(12):569-579.

15. Wei, L., Wei, Z. Z., Jiang, M. Q., Mohamad, O., \& Yu, S. P. (2017). Stemcell transplantation therapy for multifaceted therapeutic benefits after stroke. Progress in Neurobiology. 2017, 157, 49-78.

16. Zhong, J., Chan, A., Morad, L., Kornblum, H. I., Guoping Fan, \& 
Carmichael, S T.Hydrogel Matrix to Support Stem Cell Survival After Brain Transplantation in Stroke. Neurorehabilitation and Neural Repair. 2010, 24(7), 636-644.

17. Nih, L. R., Carmichael, S. T., \& Segura, T. Hydrogels for brain repair after stroke: an emerging treatment option. Current Opinion in Biotechnology. 2016, 40, 155-163.

18. Lohitash Karumbaiah, Syed Faaiz Enam, et al. Chondroitin Sulfate Glycosaminoglycan Hydrogels Create Endogenous Niches for Neural Stem Cells. Biocojugate Chemistry. 2015.

19. Jan, S. L., Hayashi, M., Kasza, Z., Eriksson, I., Bishop, J. R., Weibrecht, I., Kreuger, J. Functional Overlap Between Chondroitin and Heparan Sulfate Proteoglycans During VEGFInduced Sprouting Angiogenesis. Arteriosclerosis, Thrombosis, and Vascular Biology. 2012. 32(5), 12551263.

20. Chau, M., Deveau, T., Song, M., Gu, X., Cheng, D., Wei, L. IPS Cell Transplantation Increases Regeneration. Stem Cells. 2014.

21. Goel, A. Stem cell therapy in spinal cord injury: Hollow promise or promising science?. J Craniovert Jun Spine 2016;7:121-6.

22. Horie, N., Hiu, T., Nagata, I. Stem Cell Transplantation Enhances Endogenous Brain Repair after Experimental Stroke. Neurol Med Chir (Tokyo) 55 Suppl. 2015; 1:107-112.

23. Volpe, G., Bernstock, J. D., PeruzzottiJametti, L., Pluchino, S. Modulation of host immune responses following nonhematopoietic stem cell transplantation: Translational implications in progressive multiple sclerosis. J Neuroimmunol. 2016; (16):30312-5.

24. Yu, S. P., Wei, Z., Wei, L. Preconditioning strategy in stem cell transplantation therapy. Translational stroke research. 2013; 4:76-88.

25. Chau, M., Deveau, T. C., Song, M., Wei, Z. Z., Gu, X. Transplantation of iPS cell-derived neural progenitors overexpressing SDF-1 $\alpha$ increases regeneration and functional recovery after ischemic stroke. 2017;8(57):97537-53.

26. Francis, K. R., Wei, L. Human embryonic stem cell neural differentiation and enhanced cell survival promoted by hypoxic preconditioning. Cell Death Dis. 2010;1(2):e22.

27. Wei, N., Yu, S. P., Gu, X., Taylor, T. M., Song, D., Liu, X. F., Wei, L. Delayed intranasal delivery of hypoxic- preconditioned bone marrow mesenchymal stem cells enhanced cell homing and therapeutic benefits after ischemic stroke in mice. Cell Transplant. 2013;22(6):977-991.

28. Sun, J., Wei, Z. Z., Gu, X., et al. Intranasal delivery of hypoxiapreconditioned bone marrow-derived mesenchymal stem cells enhanced regenerative effects after intracerebral hemorrhagic stroke in mice. Exp Neurol. 2015;272:78-87.

29. Wang, K., Fu, Q., Chen, X., Gao, Y., \& Dong, K. Preparation and characterization of $\mathrm{pH}$-sensitive hydrogel for drug delivery system. RSC Advance. 2012, 2(20), 7772.

30. Li, Y., Rodrigues, J., \& Tomás, H. Injectable and biodegradable hydrogels: gelation, biodegradation and biomedical applications. Chem. Soc. Rev. 2012, 41(6), 2193-2221. 
31. Vashist, A., Vashist, A., Gupta, Y. K., \& Ahmad, S. Recent advances in hydrogel based drug delivery systems for the human body. J. Mater. Chem. B. 2014, 2(2), 147-166.

32. Strehin, I., Nahas, Z., Arora, K., Nguyen, T., \& Elisseeff, J. A versatile $\mathrm{pH}$ sensitive chondroitin sulfate-PEG tissue adhesive and hydrogel. Biomaterials. 2010, 31(10), 27882797.

33. Ghuman, H., Massensini, A. R., Donnelly, J., Kim, S.-M., Medberry, C. J., Badylak, S. F., \& Modo, M. ECM hydrogel for the treatment of stroke: Characterization of the host cell infiltrate. Biomaterials. 2016, 91, 166181.

34. Kang, I., Chang, M. Y., Wight, T. N., \& Frevert, C. W. Proteoglycans as Immunomodulators of the Innate Immune Response to Lung Infection. Journal of Histochemistry \& Cytochemistry. 2018, 66(4), 241-259.

35. Yang, J., Shen, M., Wen, H., Luo, Y., Huang, R., Rong, L., \& Xie, J. Recent advance in delivery system and tissue engineering applications of chondroitin sulfate. Carbohydrate Polymer. 2019, 115650.

36. L. Karumbaiah, T. Saxena, M. Betancur, R. V. Chondroitin sulfate glycosaminoglycans for CNS homeostasis-implications for material design. Med. Chem. 2014, 21, 4257.

37. Purushothaman, A., Sugahara, K., \& Faissner, A. Chondroitin Sulfate -Wobble Motifs\| Modulate Maintenance and Differentiation of Neural Stem Cells and Their Progeny. Journal of Biological Chemistry, 287(5), 2935-2942Volpi, N. (2019). Chondroitin sulfate safety and quality. Molecules. 2011, 24(8), 1447.
38. Townley, R. A., \& Bülow, H. E. Deciphering functional glycosaminoglycan motifs in development. Current Opinion in Structural Biology. 2018 50, 144-154.

39. Bang, S., Jung, U. W., \& Noh, I. Synthesis and Biocompatibility Characterizations of in Situ Chondroitin Sulfate-Gelatin Hydrogel for Tissue Engineering. Tissue Engineering and Regenerative Medicine. 2018, 15(1), 25-35.

40. Becker, A. M., Meyers, E., Sloan, A., Rennaker, R., Kilgard, M., \& Goldberg, M. P. An automated task for the training and assessment of distal forelimb function in a mouse model of ischemic stroke. Journal of Neuroscience Methods. 2016, 258, 1623.

41. D., Lapi A. Colantuoni, J. remodelling of cerebral microcirculation after ischemia-reperfusion. 2015, 52, 22.

42. Sébastien, L. J., Makoto, H., Zsolt, K., et al. Functional overlap between chondroitin and heparan sulfate proteoglycans during VEGF-induced sprouting angiogenesis. Arteriosclerosis, Thrombosis, and Vascular Biology. 2012;32(5):12551263.

43. 43. A. Salehi, J. H. Zhang, A. Obenaus. Response of the cerebral vasculature following traumatic brain injury. 2017 , 37, 2320.

44. Komaki S, Sugita Y, Furuta T, Yamada K, Moritsubo M, Abe H, et al. (2019). Expression of GLUT1 in Pseudopalisaded and Perivascular Tumor Cells Is an Independent Prognostic Factor for Patients With Glioblastomas. Journal of Neuropathology \& Experimental Neurology. 78. 389-397. 
45. Campbell BC, Christensen S, Tress BM, Churilov L, Desmond PM, Parsons MW, et al. Failure of collateral blood flow is associated with infarct growth in ischemic stroke. J Cereb Blood Flow Metab. 2013;33:11681172.

46. Cuccione, E., Padovano, G., Versace, A., Ferrarese, C., \& Beretta, S. Cerebral collateral circulation in experimental ischemic translational 2016. stroke. Experimental \& stroke medicine, 8,2 